\title{
Trace element concentrations in freshwater mussels and macrophytes as related to those in their environment
}

\author{
Oscar RAVERA*, Roberto CENCI ${ }^{1)}$, Gian Maria BEONE $^{2)}$, Marta DANTAS $^{3)}$ and Paolo LODIGIANI ${ }^{2)}$ \\ CNR Istituto per lo Studio degli Ecosistemi, Largo Tonolli 50, 28922 Verbania, Italy \\ ${ }^{1)}$ CCR-E.C Istituto dell'Ambiente, 21020 Ispra (VA), Italy \\ ${ }^{2)}$ Istituto di Chimica Agraria e Ambientale Università Cattolica del Sacro Cuore, Via Emilia Parmense 84, 29100 Piacenza, Italy \\ ${ }^{3)}$ Dipartimento di Scienze Ambientali, Università di Venezia, Calle Larga S. Marta 2137, 30123 Venezia, Italy \\ *e-mail corresponding author: o.ravera@ise.cnr.it
}

\begin{abstract}
This study was primarily designed to contribute to the debate "Do accumulator species reflect the element contamination level of their environment?" This research was carried out: 1) to know the distribution of 15 trace elements and calcium in shell and soft tissues of three species of freshwater mussels and macrophytes; 2) to compare the accumulation capacity of each trace element by mussels and by eight species of macrophytes and 3) to test the relationships between the metal concentrations in the mussels and macrophytes and those in water and sediments. The variability of element residues in the mussels is the major limit to accumulator monitoring. The most important causes are: seasonal cycle, physical environment and biological factors such as the size, age and growth rate. This research was designed to eliminate the consequence of variability deriving from the season and the environment. To this end the mussels and macrophytes were collected at the same time from the same habitat: Ranco Bay, Lago Maggiore, Northern Italy. In addition, the element concentrations in more size-classes of the most abundant mussel species (Unio pictorum and Dreissena polymorpha) were measured. Trace elements were analyzed by Inductive Coupled Plasma-Mass Spectrometry (ICP-MS). By arranging the data in sequences of decreasing element concentrations in the organisms as well as in water and sediments, we were able to compare the accumulating ability of the tested species and evaluate their capacity to reflect environmental availability. Neither the sequences in the shell nor those in the tissues were similar to the sequence in the water. The differences between the sequences of the mussel tissues and those of the sediments were less striking than those between shells and sediments. Similar results were obtained by macrophytes. In conclusion, the results of this study (which mimics the monitoring practice) prove that bioaccumulators cannot be used to evaluate the pollutant levels of the environment at the time of collection, since no relationship between metal concentrations in the species and those in the water was found and the relationship with the sediments was very weak. Bioaccumulators can be regarded as a useful tool in long-term studies to follow pollutant variations in the same environment or when substantial differences in pollutant concentrations in different environments were found. This monitoring method yields reliable results to detect new pollutants contaminating the environment, such as artificial radioisotopes, or to follow year to year variations by analyzing pollutant concentrations in the shell layers.
\end{abstract}

Key words: freshwater mussels, macrophytes, trace elements, calcium, bioaccumulators, Lago Maggiore

\section{INTRODUCTION}

The biomonitoring of pollutants using accumulator species is based on the capacity which have some plant and animal taxa to accumulate relatively large amounts of certain pollutants, even from very diluted solutions without obvious noxious effects.

The use of this type of monitoring is widespread in marine and freshwater environments also because the measuring of the pollutant content in the organism is the only way of evaluating the bioavailability of a pollutant present in the environment. This technique makes it possible to measure trace element concentrations even when their amounts in the physical environment are lower than the detection limits of the methods commonly used. In addition, the pollutant concentrations in the organism are the result of the past as well as the recent pollution level of the environment in which the organism lives, while the pollutant concentrations in the water only indicate the situation at the time of sampling.
The element exchangeable fraction of the sediment is commonly regarded as bioavailable. This is rather doubtful; indeed, various authors demonstrate that the relationship between the concentration of an element in an organism and that in the exchangeable fraction may be nil, positive or negative in relation to the element (Metcalfe-Smith et al. 1992). The advantages and the limits of this kind of monitoring have been discussed in another paper (Ravera 2001).

The taxa (mussels and macrophytes) considered here are among the best indicators for evaluating metal pollution in the aquatic environment.

Macrophytes concentrate great amounts of various substances (e.g. metals) and are consequently useful indicators of local pollution. The sorption of inorganic compounds by aquatic plants is facilitated by their large surface compared to their volume and the high permeability of their membranes in permanent contact with the solutes (Ravera 1966; Ravera et al. 1974; Guilizzoni 1975; Abo-Rady 1980). 
From the large volume of water they filter (e.g. Stanczikowska et al. 1976; Pusch et al. 2001), mussels uptake and accumulate in their bodies useful, non essential (es. Be, $\mathrm{Sr}, \mathrm{Ba}$ ) and also toxic metals without noxious effects (e.g. Korringa 1960; Lobel et al. 1990; Metcalfe-Smith et al. 1992; Adams \& Shorey 1998; Byrne \& Vesk 2000). The accumulation of several metals is due to the low capacity of these molluscs for discriminating among metals which are similar in some characteristics such as ionic radius (Metcalfe-Smith 1994; Jeffree et al. 1993). Mussels also possess a variety of effective detoxification mechanisms to reduce the toxicity of the metal uptaken (Byrne 2000; Mason \& Jenkins 1995; Vesk \& Byrne 1999; Byrne \& Vesk 2000). In addition, adult mussels are sedentary and some species (e.g. Dreissena polymorpha, Mytilus edulis) are geographically widespread and very abundant at all time of year. The characteristics described make mussels useful indicators of the abundance and spatial distribution of metals in aquatic ecosystems (e.g. Ravera \& Vido 1961; Gaglione \& Ravera 1964; Ferrigton et al. 1983; Czarnezki 1987; Doherty et al. 1993; Oertel 1998; Sures et al. 1999).

This paper focuses on the following subjects: a) the distribution of 15 trace elements and calcium in the shell and soft tissues of three species of freshwater mussels; b) a comparison of the accumulation capacity of the same element by mussels and by eight species of macrophytes and c) testing the relationships between the metal concentrations in the mussels and macrophytes and those in the water and sediments.

In spite of an abundance of studies on the taxa which are accumulators of pollutants, more information is required on important aspects relating to the physiology of the organisms and the relationships between the concentration of pollutant in the organism and that in the physical environment.

A major limit to accumulator monitoring is the variability of element residues in the organisms. The most important causes of variability are: seasonal cycle, physical environment, and the biological state of the organisms. Species, size, age, and probably growth rate are the major biological factors influencing variability (Metcalfe-Smith et al. 1996). The research was designed to eliminate the consequences of variability deriving from the seasonal cycle and the physical environment. To this end three species of mussels and eight of macrophytes were collected at the same time from the same habitat (Ranco Bay, Lago Maggiore, Northern Italy), facilitating the comparison among the species. In addition, because a wide variability in the size and age of the specimens of the same population may influence the monitoring (e.g. Millington \& Walker 1983), we decided to measure the element concentrations in more size-classes of Unio pictorum and Dreissena polymorpha, the most abundant species in the studied habitat.
The elements analysed were: $\mathrm{Mn}, \mathrm{Zn}, \mathrm{Cr}, \mathrm{Cu}, \mathrm{Mo}$, $\mathrm{V}, \mathrm{Co}, \mathrm{Cd}, \mathrm{Pb}, \mathrm{As}, \mathrm{Ni}, \mathrm{Sc}, \mathrm{Sb}, \mathrm{Tl}$ and Bi. The first seven elements have an important physiological role at low concentrations, while high concentrations may produce harmful effects. Cadmium, lead, arsenic and nickel are dangerous pollutants, and the information available on the biological role of scandium, antimony and bismuth is very poor. Some authors (e.g. Jeffree et al. 1993; Walker et al. 2001) have found relationships between calcium concentration and those of some trace metals in mussels. Consequently, it seemed to be of interest to analyse the concentration of calcium in our samples.

\section{MATERIAL AND METHODS}

Water, surface sediments, macrophytes and mussels were collected on September $15^{\text {th }} 2000$ from a small, shallow bay located at Ranco, a village near Angera on the western shore of Lago Maggiore (Fig. 1). No sewage or industrial effluents discharge into the bay. In recent years Lago Maggiore has been re-classified as oligomesotrophic, as a result both of an effective sewage treatment plan and the progressive decrease of the phosphate percentage added to detergents. The annual water temperature of the bay ranges from $6{ }^{\circ} \mathrm{C}$ to $25^{\circ} \mathrm{C}$; when our samples where collected the temperature was $23^{\circ} \mathrm{C}$.

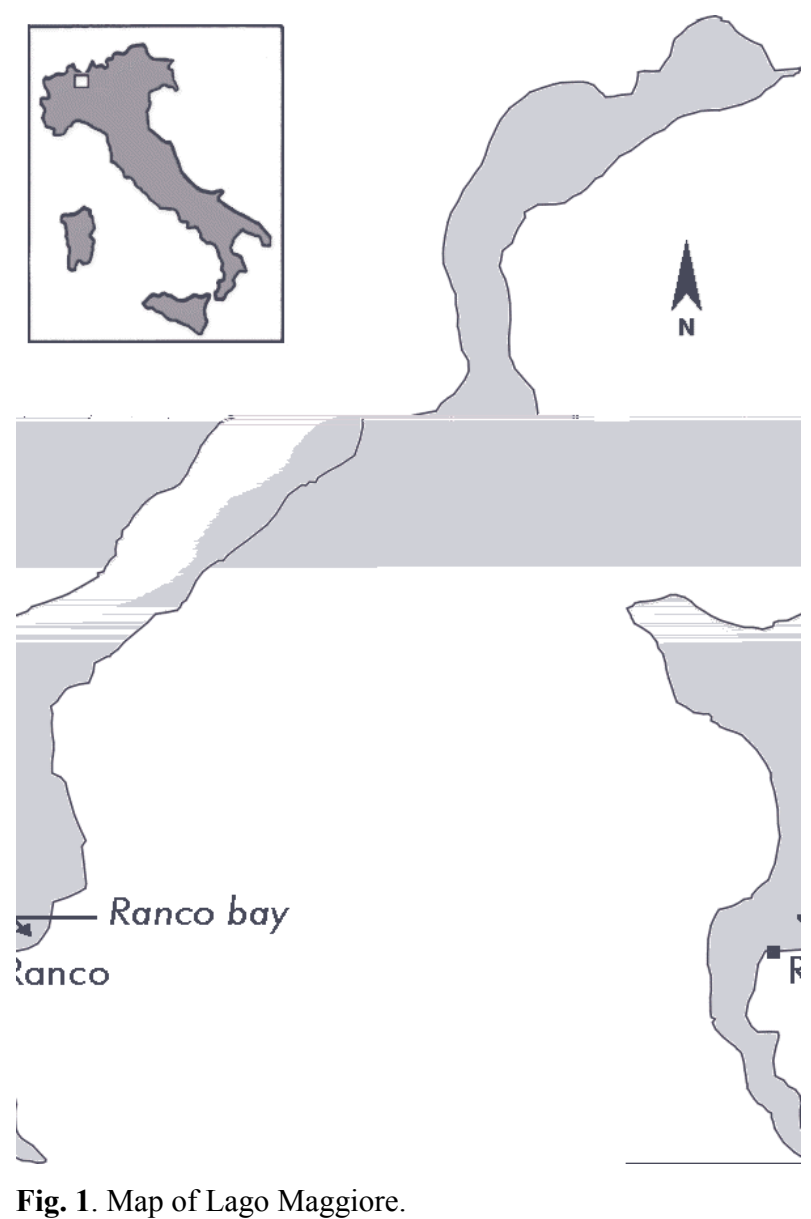


The plant species collected were six phanerophytes (Ceratophyllum demersum, L., Lagarosiphon major (Ridley) Moss, Myriophyllum spicatum, L., Najas marina, L., Potamogeton crispus, L., Vallisneria spiralis, L.) and two species of the genus Nitella (Charales). Two of the Mollusca Bivalvia species collected belonged to the Unionidae (Unio pictorum mancus ${ }^{1 \text { ) }}$ and Anodonta cygnea, L.) and one to the Dreissenidae (Dreissena polymorpha, Pallas).

Samples of water, sediment, aquatic plants and molluscs were taken from various areas of the bay at a maximum depth of 1 meter. Soon after collection, the water samples were filtered on $0.45 \mu \mathrm{m}$ (pore size) Millipore filter and preserved in plastic bottles by the addition of a few drops of nitric acid. Sediments were preserved in plastic bags. Macrophytes: were collected by hand and, after careful washing with lake water to remove periphyton, were preserved in plastic bags. The length of each bivalve shell was measured and the soft tissues removed from the shell. The film of mineral and organic particles and organisms (e.g. algae) coating the periostracum of the mussel shell was carefully removed by brushing with a nylon nailbrush. The mussels were then washed in lake water and preserved in plastic bags. All the samples collected were placed in ice and rushed to the laboratory where they were kept in an ice-box al $20{ }^{\circ} \mathrm{C}$ until analysed.

The mussels were frozen without being permitted to clear their digestive tract, eliminating the undigested material and its content of trace element. According to Metcalfe-Smith (1994) and other authors, the gut contains a negligible amount of trace element compared to the whole body content. To prevent this cause of error some authors starved the mussels for long enough to void the gut. Because complete depuration requires at least six days (Jeffree et al. 1993), long enough to eliminate a more or less important fraction of the uptaken elements (Ünlü \& Fowler 1979), the clearing of the digestive tract may be also a more important cause of error.

Ten specimens of Unio and Anodonta were dissected into various organs (mantle, gills, visceral sac and adductor muscles) and preserved separately.

Aquatic plants and the soft tissues of the mussels were freeze-dried and then kept at $40{ }^{\circ} \mathrm{C}$ for 24 hours. All the samples were pulverised in a Planetary Micro Mill using agate as well as the balls. Before pulverisation the shells were broken into several pieces. The powder obtained was selected using by a plastic sieve with $2 \mathrm{~mm}$ opening size. The samples were mineralised by the Micro Wave Digestion System 2000 using $\mathrm{HNO}_{3}$ $(65 \%)$ and $\mathrm{H}_{2} \mathrm{O}_{2}$ at $180{ }^{\circ} \mathrm{C}$ and a pressure of 1300 psi.

\footnotetext{
${ }^{1)}$ According to Nagel \& Badino (2001) the species Unio mancus, Lamarck is a sub-species of $U$. pictorum, L. $U$. pictorum is a polytypic species which comprises populations from Mediterranean area known as U. pictorum mancus, and populations from Central, Northern and Eastern Europe called U. p. pictorum.
}

The solution obtained after sample digestion was diluted, filtered onto paper and analyzed for trace elements by the Inductive Coupled Plasma - Mass Spectrometry (ICPMS). This technique permits the measurement of a series of elements at the same time. The instrument sensitivity is $1 \mathrm{ppb}$ for almost all the elements investigated. Sample volume ranged from 10 to $50 \mathrm{ml}$ and was injected by an MCN-Cetac nebulizer (USA).

The precision and accuracy of the measurements were checked by replications and certified standards (BRC 258). All the trace elements, except for calcium, were analysed by R. Cenci and co-workers (Institute of the Environment, Joint Research Center, E.C., Ispra, VA, Italy) using an ICP-MS instrument. Calcium, which was always present in relatively high concentrations in our samples, was analysed by G.M. Beone and coworkers (Istituto di Chimica Agraria e Ambientale, Università Cattolica del Sacro Cuore, Piacenza, Italy) using an ICP-AES JY24. The high sensitivity of the ICP-MS instrument makes it suitable for measuring very low concentrations. To measurement of high concentrations requires a series of dilutions, which is always a source of errors. The ICP-AES instrument has the same advantages as the ICP-MS, but its sensitivity is lower. When element concentrations are high, the dynamic range of the ICP-AES (the ICP has a linear range of about 105) may represent an advantage because there is no need for sample dilution. Each sample analyzed was composed by ten mussels.

To quantify the comparison of the concentration of an element in an aquatic organism with that of the same element in the water in which the organism lives, we can use the ratio between the concentration of the element in the organism (related to the wet weight) and that in the water. The value of this ratio is known as the concentration factor (C.F.). This factor may be calculated when in an organism the concentration of a certain element is (or is not) at equilibrium level with that in the water, the first case is described as the "real C.F." or "C.F. at equilibrium", the second is the "observed C.F." (De Bortoli et al. 1968). When the C.F. value is at equilibrium, the release rate of the element from the organism is equivalent to its intake rate, so that the element concentration in the organism is fairly constant. This may occur if the element concentration in the water is constant over time and the organism is in a physiological steady state. As a consequence, the "observed concentration factor" is less informative than the C.F. at equilibrium. In our case we may suppose that the C.F. values are close to equilibrium with the element concentrations in the water, because macrophytes and mussels are sedentary and the pollutant load into the bay of Ranco is steady and fairly low.

Because the concentration factor (C.F.) is expressed by the ratio between the concentration of the element in the organism (or in a part of it), calculated on the wet weight and the concentration in the water, the element 
concentration based on the dry weight must be converted into concentration on the wet weight. To this end the dry weight concentrations were divided for the ratio between wet weight and dry weight of the shell, soft tissues and macrophytes. These ratios were the following: 1.02 for shell of Unio and Anodonta; 1.06 for shell of Dreissena; 5.38 for tissues of Unio; 7.58 for those of Anodonta, 4.00 for those of Dreissena and 10 for macrophytes.

\section{RESULTS}

\subsection{Water and sediments}

The concentrations of the elements considered were far higher in the sediments than those calculated for the same elements in the lake water filtered onto Millipore filter $(0.45 \mu \mathrm{m}$ opening size $)$. The values of the ratio between element concentrations in the sediments and those in the water were lower than $10^{3}$ for $\mathrm{Cr}, \mathrm{Zn}, \mathrm{Ni}$, $\mathrm{Mo}, \mathrm{Sb}$ and $\mathrm{Ca}$, whereas those of the other elements ranged between 1200 for $\mathrm{Cu}$ and 22100 for $\mathrm{Mn}$ (Tab. 1). The concentrations in the water of the elements with a ratio lower than $10^{3}$ were higher than $1.9 \mu \mathrm{g} \mathrm{l}^{-1}$, except for $\mathrm{Sb}\left(0.8 \mu \mathrm{g} \mathrm{l}^{-1}\right)$, while the elements with a ratio higher than $10^{3}$ had concentrations in the water equal to or lower than $1.9 \mu \mathrm{g}^{-1}$.

Tab. 1. Element concentrations in sediments and water and ratios between the concentration in the sediments and that in the water.

\begin{tabular}{lccc}
\hline & $\begin{array}{c}\text { sediment } \\
\left(\mu \mathrm{g} \mathrm{kg}^{-1} \mathrm{ww}\right)\end{array}$ & $\begin{array}{c}\text { water } \\
\left(\mu \mathrm{g} \mathrm{l}^{-1}\right)\end{array}$ & sediment/water \\
\hline $\mathrm{Mn}$ & 24340 & 1.1 & 22137 \\
$\mathrm{Zn}$ & 7930 & 33.0 & 240 \\
$\mathrm{Cu}$ & 1350 & 1.1 & 1227 \\
$\mathrm{As}$ & 4300 & 1.9 & 3909 \\
$\mathrm{Cd}$ & 0.28 & 0.01 & 2800 \\
$\mathrm{Ni}$ & 1110 & 8.6 & 129 \\
$\mathrm{~Pb}$ & 1447 & 0.12 & 12058 \\
$\mathrm{Mo}$ & 17 & 2.6 & 7 \\
$\mathrm{Cr}$ & 1820 & 1.9 & 958 \\
$\mathrm{~V}$ & 2120 & 0.43 & 4930 \\
$\mathrm{Sc}$ & 496 & 0.20 & 2480 \\
$\mathrm{Co}$ & 400 & 0.06 & 6667 \\
$\mathrm{Sb}$ & 2 & 0.77 & 3 \\
$\mathrm{Bi}$ & 14 & 0.01 & 1400 \\
$\mathrm{Ca}$ & 719300 & 13990 & 51 \\
\hline
\end{tabular}

Of the elements analyzed Ca was the most abundant in both sediments (719 mg kg-1 wet weight) and water $\left(14 \mathrm{mg} \mathrm{l}^{-1}\right)$, followed by $\mathrm{Mn}$ with a concentration of 24 $\mathrm{mg} \mathrm{kg}^{-1}$ w.w. in the sediments and $1.1 \mu \mathrm{g} \mathrm{l}^{-1}$ in the water. The concentration of $\mathrm{Mn}$ is low in the water and high in the sediments due to the precipitation of this element in an environment such as that of the Bay of Ranco, where there is a high concentration of dissolved oxygen.

\subsection{Macrophytes}

Table 2 shows the values of the 16 element concentrations in eight species of macrophytes. In addition to the 15 trace elements, calcium concentrations are considered because of the influence of this element on the uptake and accumulation of some other elements. The mean concentration values of the elements in the plants decrease according to this sequence: $\mathrm{Ca}>\mathrm{Mn}>\mathrm{Zn}>\mathrm{Ni}$ $>\mathrm{Cu}>\mathrm{V}>\mathrm{Pb}>\mathrm{Cr}>\mathrm{Sc}>\mathrm{As}>\mathrm{Co}>\mathrm{Mo}>\mathrm{Cd}>\mathrm{Tl}>$ $\mathrm{Bi}>\mathrm{Sb}$.

Vallisneria has the greatest capacity for concentrating trace elements. In fact, this species shows the highest concentrations of 9 elements $(\mathrm{Mn}, \mathrm{Zn}, \mathrm{Cu}, \mathrm{Pb}, \mathrm{V}, \mathrm{Cr}$, $\mathrm{As}, \mathrm{Co}$ and $\mathrm{Bi}$ ) out of 16 , and 14 elements have concentrations higher than their mean value. Conversely, Najas has the lowest concentrations for 11 of the 16 elements considered $(\mathrm{Ca}, \mathrm{Zn}, \mathrm{Ni}, \mathrm{Cu}, \mathrm{Pb}, \mathrm{V}, \mathrm{Cr}$, As, Co, $\mathrm{Tl}$ and $\mathrm{Bi}$ ). The low values calculated for this species may be due, at least in part, to the smooth surface of their leaves, which by reducing the ratio between surface area and volume may decrease the adsorption of elements as well as preventing periphyton colonisation. Periphyton, always difficult to remove completely from the plant, may concentrate large amounts of several elements. The high concentrations of calcium in Lagarosiphon $\left(\mu \mathrm{g} 93741 \mathrm{~g}^{-1}\right.$ d.w.) and Potamogeton $(\mu \mathrm{g}$ $90487 \mathrm{~g}^{-1}$ d.w.) are probably due to encrustations of calcium carbonate on its leaves which cannot be completely removed by washing.

Table 3 gives the C.F. (concentration factor) values calculated for each species and element. Thallium was not analysed in the water, because its concentration was lower than the detection limit of the method, preventing the calculation of its C.F. The mean C.F. values of the elements in the plants decrease according to this sequence: $\mathrm{Mn}>\mathrm{Pb}>\mathrm{Co}>\mathrm{Cd}>\mathrm{Sc}>\mathrm{V}>\mathrm{Cu}>\mathrm{Bi}>\mathrm{Cr}>$ $\mathrm{As}>\mathrm{Ca}>\mathrm{Zn}>\mathrm{Ni}>\mathrm{Mo}>\mathrm{Sb}$. This sequence (which is rather different from that of the mean concentrations of elements in the plants) reflects the capacity of the macrophytes to accumulate elements independently from their concentration in the water, that is the regulation capacity of the plants. Concentration factors for the various elements calculated for Vallisneria are generally rather high, while those for Najas are lower than those of the other species.

In conclusion, macrophytes are demonstrated to be efficient concentrators for all the elements considered.

\subsection{Mussels}

Table 4 shows the element concentrations in the shell and soft tissues of Unio, Anodonta and Dreissena. $\mathrm{Ni}, \mathrm{Mo}, \mathrm{Cr}, \mathrm{V}$ and $\mathrm{Sb}$ concentrations were higher in the shell of these three species than in the soft tissues; conversely $\mathrm{Mn}, \mathrm{Zn}, \mathrm{Cu}, \mathrm{As}, \mathrm{Cd}$ and $\mathrm{Pb}$ concentrations were higher in the soft tissues than in the shell.

Interestingly, the manganese concentrations in the shell and soft tissues of Dreissena are much lower than 
Tab. 2. Element concentrations $\left(\mu \mathrm{g} \mathrm{g}^{-1} \mathrm{dw}\right)$ of the elements in the macrophyte species. MDL $=$ Method Detection Limit. ${ }^{(1)}$ a) and b) Nitella are two different not identified species.

\begin{tabular}{lcccccccccccccccc}
\hline Element/taxon & $\mathrm{Mn}$ & $\mathrm{Zn}$ & $\mathrm{Cu}$ & $\mathrm{As}$ & $\mathrm{Cd}$ & $\mathrm{Ni}$ & $\mathrm{Pb}$ & $\mathrm{Mo}$ & $\mathrm{Cr}$ & $\mathrm{V}$ & $\mathrm{Sc}$ & $\mathrm{Co}$ & $\mathrm{Sb}$ & $\mathrm{Tl}$ & $\mathrm{Bi}$ & $\mathrm{Ca}$ \\
\hline a) Nitella $(1)$ & 225 & 96 & 19 & 9 & 0.26 & 17 & 20 & 1.00 & 13 & 18 & 7 & 4 & 0.10 & 0.14 & 0.15 & 40571 \\
b) Nitella & 186 & 69 & 11 & 5 & 0.19 & 9 & 14 & 0.23 & 9 & 16 & 6 & 3 & 0.08 & 0.12 & 0.11 & 17709 \\
Lagarosiphon $_{\text {Vallisneria }}$ & 216 & 84 & 13 & 4 & 0.31 & 44 & 9 & 11 & 14 & 10 & 5 & 2 & 0.23 & 0.20 & 0.09 & 93741 \\
Myriophyllum & 2938 & 143 & 26 & 11 & 0.79 & 21 & 20 & 0.98 & 18 & 27 & 10 & 4 & 0.13 & 0.18 & 0.19 & 19022 \\
Ceratophyllum & 265 & 61 & 19 & 6 & 0.44 & 14 & 20 & 0.46 & 13 & 15 & 11 & 3 & 0.11 & 0.14 & 0.18 & 19117 \\
Potamogeton & 219 & 71 & 13 & 4 & 0.07 & 12 & 9 & 0.23 & 11 & 12 & 7 & 2 & $<\mathrm{MDL}$ & 0.16 & 0.09 & 90487 \\
Najas & 198 & 46 & 9 & 2 & 0.43 & 9 & 7 & $<\mathrm{MDL}$ & 6 & 6 & 7 & 1 & 0.11 & 0.10 & 0.06 & 13290 \\
mean & 279.88 & 83 & 16.63 & 5.75 & 0.43 & 18.25 & 14.75 & 2.06 & 12.38 & 15.12 & 8.12 & 2.75 & 0.12 & 0.15 & 0.13 & 38712 \\
SD & 148.77 & 29.48 & 6.05 & 2.92 & 0.30 & 11.36 & 5.70 & 3.96 & 3.70 & 6.04 & 2.53 & 1.03 & 0.05 & 0.03 & 0.05 & 34013 \\
\hline
\end{tabular}

Tab. 3. Concentration factors calculated for the various species and elements. The values must be multiplied for $10^{2}$. MDL $=$ Method Detection Limit. ${ }^{(1)}$ a) and b) Nitella are two different not identified species.

\begin{tabular}{|c|c|c|c|c|c|c|c|c|c|c|c|c|c|c|c|}
\hline Element/taxon & $\mathrm{Mn}$ & $\mathrm{Zn}$ & $\mathrm{Cu}$ & As & $\mathrm{Cd}$ & $\mathrm{Ni}$ & $\mathrm{Pb}$ & Mo & $\mathrm{Cr}$ & V & $\mathrm{Sc}$ & Co & $\mathrm{Sb}$ & $\mathrm{Bi}$ & $\mathrm{Ca}$ \\
\hline b) Nitella ${ }^{(1)}$ & 169 & 2.1 & 10 & 2.6 & 19 & 1.0 & 117 & 0.09 & 4.7 & 37 & 30 & 50 & 0.10 & 11 & 1 \\
\hline Vallisneria & 580 & 4.3 & 24 & 5.8 & 79 & 2.4 & 167 & 0.38 & 9.5 & 63 & 50 & 67 & 0.17 & 19 & 1 \\
\hline Myriophyllum & 265 & 1.8 & 17 & 3.2 & 44 & 1.6 & 167 & 0.18 & 6.8 & 35 & 55 & 50 & 0.14 & 18 & 1 \\
\hline Ceratophyllum & 241 & 2.8 & 21 & 2.6 & 97 & 2.3 & 158 & 0.19 & 7.9 & 39 & 60 & 50 & 0.12 & 18 & 1 \\
\hline mean & 254 & 2.37 & 15.12 & 3.01 & 43.25 & 2.26 & 123 & 0.79 & 6.51 & 35.12 & 40.62 & 45.87 & 0.16 & 13.12 & 2.62 \\
\hline SD & 135 & 0.91 & 5.57 & 1.54 & 30.5 & 1.35 & 47.66 & 1.52 & 1.95 & 14.57 & 12.66 & 17.36 & 0.07 & 5.00 & 2.50 \\
\hline
\end{tabular}

Tab. 4. Concentration of elements $\left(\mu \mathrm{g} \mathrm{g}^{-1} \mathrm{dw}\right)$ in shell and soft tissues of Unio pictorum mancus (U), Anodonta cygnea (A) and Dreissena polymorpha (D). MDL $=$ Method Detection Limit.

\begin{tabular}{lccccccc}
\hline \multirow{2}{*}{ Element } & \multicolumn{3}{c}{ shell } & & & \multicolumn{3}{c}{ soft tissues } \\
\cline { 2 - 4 } \cline { 7 - 8 } & $\mathrm{U}$ & $\mathrm{A}$ & $\mathrm{D}$ & & $\mathrm{U}$ & $\mathrm{A}$ & $\mathrm{D}$ \\
\hline $\mathrm{Mn}$ & 220 & 289 & 28 & & 5092 & 11258 & 74 \\
$\mathrm{Zn}$ & 19 & 46 & 15 & & 361 & 642 & 137 \\
$\mathrm{Cu}$ & 6 & 11 & 2 & & 13 & 34 & 50 \\
$\mathrm{As}$ & 2 & 2 & 0.9 & & 12 & 13 & 9 \\
$\mathrm{Cd}$ & 0.7 & 0.3 & 1 & & 5 & 10 & 4 \\
$\mathrm{Ni}$ & 1425 & 270 & 160 & & 5 & 5 & 13 \\
$\mathrm{~Pb}$ & 0.4 & 1 & 1 & & 11 & 23 & 5 \\
$\mathrm{Mo}$ & 488 & 104 & 61 & & 0.5 & 1 & 0.8 \\
$\mathrm{Cr}$ & 450 & 93 & 55 & & 2 & 0.4 & $<\mathrm{MDL}$ \\
$\mathrm{V}$ & 6 & 3 & 3 & & 0.6 & 2 & 2 \\
$\mathrm{Sc}$ & $<\mathrm{MDL}$ & 0.7 & 0.6 & & 0.3 & 1 & 0.8 \\
$\mathrm{Co}$ & 2 & 1 & 0.8 & & 0.7 & 1 & 1 \\
$\mathrm{Sb}$ & 8 & 1 & 0.7 & & 0.1 & 0.2 & 0.2 \\
$\mathrm{Tl}$ & $<\mathrm{MDL}$ & $<\mathrm{MDL}$ & $<\mathrm{MDL}$ & & 0.02 & 0.03 & 0.05 \\
$\mathrm{Bi}$ & 0.01 & 1 & 0.02 & & 0.03 & 0.1 & 0.1 \\
$\mathrm{Ca}$ & 406288 & 383631 & 399703 & & 39108 & 74119 & 9162 \\
\hline
\end{tabular}

those measured in the shells and tissues of the Unionidae Unio and Anodonta. Calcium concentrations in the shell of the three species are similar, while the concentrations in the soft tissues show great differences between species, with the highest value in Anodonta and the lowest in Dreissena. Accordingly the concentrations of $\mathrm{Mn}$ and $\mathrm{Zn}$ decrease from Anodonta to Unio and from Unio to Dreissena. The reason for this may lie in the calcium-mimic hypothesis which suggests that mussels uptake some trace metals as metabolic analogues of calcium (Jeffree \& Brown 1992; Jeffree et al. 1993; Markich \& Jeffree 1994).
We estimated the distribution of the elements in the various organs of Unio and Anodonta (Tab. 5). The elements which show a greater concentration in the shell are: $\mathrm{Ca}, \mathrm{Ni}, \mathrm{Mo}, \mathrm{Cr}, \mathrm{Mn}$ and $\mathrm{Zn}$ (Tab. 4). High concentrations of calcium were also measured in the soft tissues and particularly in the gills and mantle. These organs show the highest concentrations of $\mathrm{Mn}$ and $\mathrm{Zn}$ and high concentrations of $\mathrm{Cu}, \mathrm{As}, \mathrm{Pb}, \mathrm{Ni}$ and $\mathrm{Cd}$. The adductor muscles had the lowest concentrations of all the elements.

If the total content of each element is considered, the greatest amounts of $\mathrm{Mn}$ and $\mathrm{Zn}$ are clearly accumulated 
Tab. 5. Element concentrations ( $\left.\mu \mathrm{g} \mathrm{g}^{-1} \mathrm{dw}\right)$ in the gills, mantle, visceral sac and adductor muscles of Unio pictorum mancus and Anodonta cygnea. Concentrations in the shell are reported in table 4 . The dry weight of the organs are reported in figure 2. MDL $=$ Method Detection Limit.

\begin{tabular}{|c|c|c|c|c|c|c|c|c|}
\hline \multirow[t]{2}{*}{ Element } & \multicolumn{4}{|c|}{ UNIO } & \multicolumn{4}{|c|}{ ANODONTA } \\
\hline & Gills & Mantle & Sac & Muscles & Gills & Mantle & Sac & Muscles \\
\hline $\mathrm{Mn}$ & 15203 & 5991 & 1198 & 1622 & 19731 & 13106 & 2843 & 2676 \\
\hline $\mathrm{Zn}$ & 967 & 381 & 148 & 150 & 960 & 839 & 235 & 201 \\
\hline $\mathrm{Cu}$ & 15 & 15 & 15 & 5 & 26 & 64 & 20 & 7 \\
\hline As & 14 & 9 & 15 & 7 & 13 & 13 & 13 & 6 \\
\hline $\mathrm{Cd}$ & 13 & 7 & 3 & 3 & 11 & 15 & 6 & 2 \\
\hline $\mathrm{Ni}$ & 15 & 2 & 5 & 0.7 & 8 & 7 & 2 & 1 \\
\hline $\mathrm{Pb}$ & 22 & 13 & 6 & 5 & 28 & 34 & 11 & 6 \\
\hline Mo & 2 & $<\mathrm{MDL}$ & 0.4 & 0.2 & 1 & 1 & 0.7 & 0.3 \\
\hline $\mathrm{Cr}$ & 8 & 3 & $<\mathrm{MDL}$ & $<\mathrm{MDL}$ & $<\mathrm{MDL}$ & 1 & $<\mathrm{MDL}$ & $<\mathrm{MDL}$ \\
\hline V & 1 & 1 & 0.5 & 0.2 & 0.7 & 3 & 2 & 0.6 \\
\hline $\mathrm{Sc}$ & $<\mathrm{MDL}$ & $<\mathrm{MDL}$ & 0.6 & 0.2 & 1 & 2 & 1 & 1 \\
\hline Co & 1 & 0.7 & 0.7 & 0.4 & 1 & 2 & 1 & 0.5 \\
\hline $\mathrm{Sb}$ & 0.2 & 0.1 & 0.1 & 0.1 & 0.1 & 0.3 & 0.2 & 0.2 \\
\hline $\mathrm{Tl}$ & 0.1 & 0.03 & 0.01 & $<\mathrm{MDL}$ & 0.03 & 0.04 & 0.02 & 0.01 \\
\hline $\mathrm{Bi}$ & 0.04 & 0.05 & 0.03 & 0.03 & 0.1 & 0.2 & 0.1 & $<\mathrm{MDL}$ \\
\hline $\mathrm{Ca}$ & 114133 & 44983 & 10690 & 13372 & 148955 & 56376 & 25151 & 21425 \\
\hline
\end{tabular}

in the soft tissues, especially the gills and mantle, in spite of the small mass of these organs. Most of the $\mathrm{Ca}$ and almost all the $\mathrm{Ni}$, Mo and $\mathrm{Cr}$ were in the shell. It is interesting to note that, on a dry weight basis, the soft tissues represent the smallest part of the entire mean individual: 17\% in Unio and 28\% in Anodonta (Fig. 2).
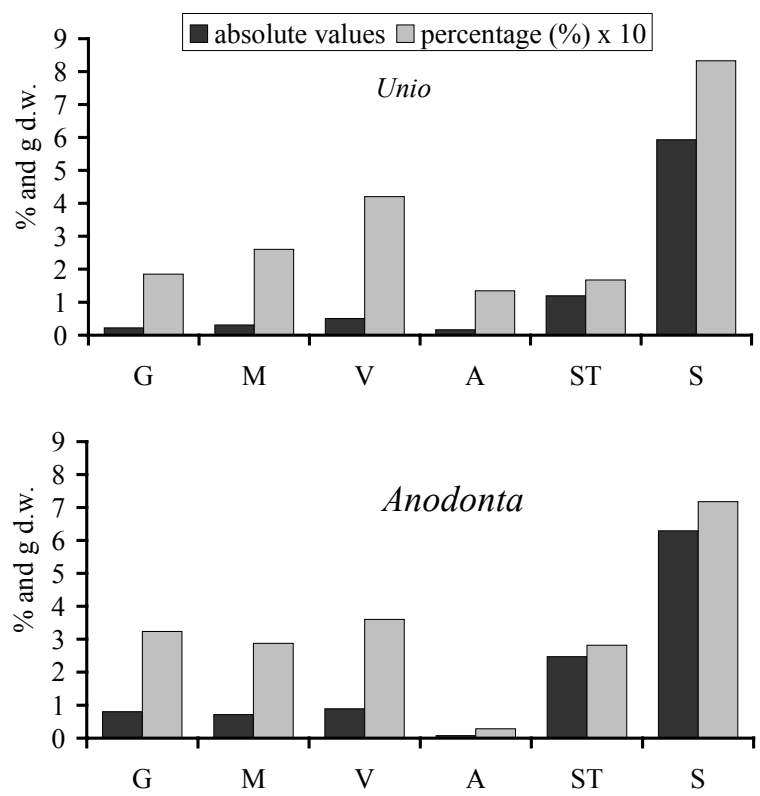

Fig. 2. Mean dry weight of gills $(\mathrm{G})$, mantle $(\mathrm{M})$, visceral sac (V), adductor muscle (A), total soft tissues (ST) and shell (S). The percentages of the organs are related to the total soft tissues; those of the total soft tissues and the shell to the weight of the total mussel. The mean lenght of Unio ranges between 45 and $60 \mathrm{~mm}$, that of Anodonta between 65 and $72 \mathrm{~mm}$.
It may be presumed that molluscs of the same species and size-class living in the same ecosystem belong to the same age-class. On this statement, shells and soft tissues of Unio and Dreissena belonging to different size-classes were analysed for $\mathrm{Ca}$ and trace elements to ascertain if the age of the mollusc may influence the element accumulation. The data obtained highlight a certain tendency for Mn concentrations in the shell and soft tissues to increase with age (Fig. 3). This was also observed for fall-out Mn-54 in Unio from different areas of Lago Maggiore (Ravera 1964). The high concentration of this metal in Unionidae seems to be the effect of its analogy with calcium rather than being a physiological requirement of the mussels. No relationship between metal concentration and the size of the mollusc can be established for the other metals.

Table 6 report the concentration factor (C.F.) values calculated for the metal in shell and soft tissues of Unio, Anodonta and Dreissena. The C.F. values varied with the species, and in the same species the differences between shell and tissues are often very great. Generally speaking, the values for the shell were higher than those calculated for the soft tissues. Mn shown a C.F. $10^{5}$ higher in both shell and tissues of the Unionidae, while Cd has a C.F. of the same value for shell and tissues in Dreissena. In addition, high C.F. were calculated for $\mathrm{Ni}$, $\mathrm{Mo}$ and $\mathrm{Cr}$ in the shell of Unio and for $\mathrm{Bi}$ in that of Anodonta. Comparatively low values (ranging between $10^{3}$ and $10^{4}$ ) for $\mathrm{Zn}, \mathrm{As}$ and Co were calculated in the soft tissues of the three species. Interestingly, the C.F. values for $\mathrm{Ni}$ in the three species were higher in the shell than in the tissues, while for $\mathrm{Zn}$ the values were higher in the tissues than in the shell. 
Tab. 6. Concentration factor (C.F.) of the various elements calculated for the shell and soft tissues of Unio pictorum mancus (U), Anodonta cygnea (A) and Dreissena polymorpha (D). The values must be multiplied for $10^{3}$. MDL $=$ Method Detection Limit.

\begin{tabular}{lccccccc}
\hline Element & \multicolumn{3}{c}{ shell } & & & \multicolumn{3}{c}{ soft tissues } \\
\cline { 2 - 4 } \cline { 6 - 8 } & $\mathrm{U}$ & $\mathrm{A}$ & $\mathrm{D}$ & & $\mathrm{U}$ & $\mathrm{A}$ & $\mathrm{D}$ \\
\hline $\mathrm{Mn}$ & 196 & 257 & 24 & & 890 & 1350 & 17 \\
$\mathrm{Zn}$ & 0.58 & 1.36 & 0.42 & & 2 & 3 & 1 \\
$\mathrm{Cu}$ & 5 & 10 & 2 & & 2 & 5 & 12 \\
$\mathrm{As}$ & 1 & 1 & 0.44 & & 1 & 1 & 1 \\
$\mathrm{Cd}$ & 70 & 29 & 100 & & 93 & 132 & 100 \\
$\mathrm{Ni}$ & 162 & 31 & 18 & & 0.11 & 0.1 & 0.35 \\
$\mathrm{~Pb}$ & 3 & 8 & 8 & & 17 & 25 & 8 \\
$\mathrm{Mo}$ & 184 & 39 & 22 & & 0.04 & 0.05 & 0.1 \\
$\mathrm{Cr}$ & 232 & 48 & 27 & & 0.19 & 0.03 & $<\mathrm{MDL}$ \\
$\mathrm{V}$ & 14 & 7 & 7 & & 0.26 & 0.07 & 1.16 \\
$\mathrm{Sc}$ & $<\mathrm{MDL}$ & 4 & 3 & & 0.25 & 0.65 & 0.1 \\
$\mathrm{Co}$ & 33 & 17 & 13 & & 2 & 2 & 4 \\
$\mathrm{Sb}$ & 10 & 0.13 & 0.9 & & 0.02 & 0.04 & 0.06 \\
$\mathrm{Bi}$ & 1 & 100 & 2 & & 0.6 & 1 & 3 \\
$\mathrm{Ca}$ & 28 & 27 & 27 & & 0.5 & 0.7 & 0.16 \\
\hline
\end{tabular}
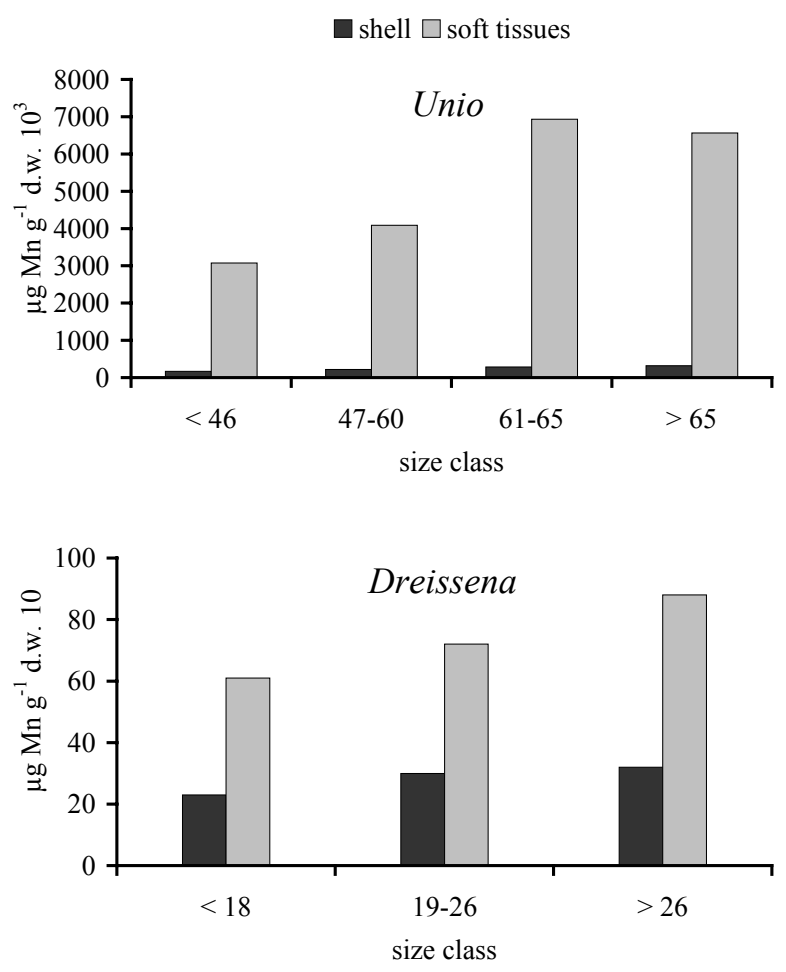

Fig. 3. Concentrations of manganese in shell and soft tissues of Unio pictorum mancus and Dreissena polymorpha belonging to various size classes (expressed in $\mathrm{mm}$ ).

\section{DISCUSSION AND CONCLUSIONS}

This study was primarily designed to contribute to the debate: "Do accumulator organisms reflect the element contamination level of their environment?"

An organism is expected to reflect environmental pollution if it has the ability to take up elements proportionally to their concentration in the environment. This is more likely to occurs in organisms with little capacity for discriminating between different elements, which are therefore accumulated independently from the organism's physiological needs. This is exemplified by the high concentration of manganese which can be accumulated by the Unionidae. However, the ideal accumulator organism does not exist, since many species have a more or less effective capacity for regulating their metal body burden. The body burden can increase with element availability until it reaches a threshold above which no further increase is possible in response to environmental increases.

Assuming a proportionality between element concentrations in the organisms and in the environment (which is the background concept in biomonitoring), the sequence of the concentrations of the different elements in the organisms should reflect the sequence in the water and/or in the sediments. By arranging the data of this study in sequences of decreasing metal concentrations in the organisms as well as in water and sediments, we were able to compare the accumulating ability of the tested species and evaluate their capacity to reflect environmental availability. As environmental metal concentrations and their physico-chemical forms are the same for all the organisms (which were collected at the same time and from the same habitat), any differences can be attributed to the species.

The eight species of aquatic plants showed a similarity in the concentration sequence for the metals with a high $(\mathrm{Ca}, \mathrm{Mn}, \mathrm{Zn})$ and very low $(\mathrm{Cd}, \mathrm{Tl}, \mathrm{Bi}, \mathrm{Sb})$ concentrations, while there were marked differences between the species for metals with intermediate concentrations. For instance, vanadium comes $4^{\text {th }}$ (after $\mathrm{Ca}$, $\mathrm{Mn}, \mathrm{Zn}$ ) in the metal concentration sequence in Vallisneria while it is in the $8^{\text {th }}$ place in Lagarosiphon (after $\mathrm{Ca}, \mathrm{Mn}, \mathrm{Zn}, \mathrm{Ni}, \mathrm{Cr}, \mathrm{Cu}$ and $\mathrm{Mo}$ ). The sequence of metal 
concentrations in the macrophytes differed substantially from the sequence in the water; and there was a certain similarity with the sequence in the sediments.

Mussels are more complex organisms than macrophytes in so far as they are a system made up of two very different compartments: shell and soft tissues. The chemical composition of the shell is the result of the of shell production process performed by soft tissues, namely the mantle and the extrapalleal liquid. The turnover rate of the metals is much slower in the shell than in the soft tissues.

The sequence of decreasing element concentrations in the shell of the three mussel species (Unio, Anodonta, Dreissena) differed considerably from the sequence in the soft tissues. A similarity between the sequences in Unio and Anodonta shells and soft tissues was observed, particularly for the elements with higher concentrations, namely $\mathrm{Ca}, \mathrm{Mn}, \mathrm{Mo}, \mathrm{Ni}, \mathrm{Cr}$, and $\mathrm{Zn}$ in the shells and $\mathrm{Ca}, \mathrm{Mn}, \mathrm{Zn}, \mathrm{Cu}, \mathrm{Pb}, \mathrm{As}, \mathrm{Cd}$ and $\mathrm{Ni}$ in the soft tissues. In Dreissena the sequence of element concentrations in the shell and in the soft tissues was fairly similar to the sequence observed in Unionidae, but there was less similarity than that between Unio and Anodonta. However, once again the similarity was closer for the elements with higher concentrations in the shell $(\mathrm{Ca}, \mathrm{Mn}, \mathrm{Mo}, \mathrm{Ni}$, $\mathrm{Cr}, \mathrm{Zn}$ ) and soft tissues (Ca, $\mathrm{Mn}, \mathrm{Zn}, \mathrm{Cu}$ ) than for those with low concentrations.

Neither the sequences of element concentrations in the shell nor those in the soft tissues in any of the three mussel species were similar to the sequence of element concentrations in the water, the difference being smaller for the shells than for the soft tissues. Wide differences between the shell sequences of the shell of the three species and the sediment sequence were also observed. For instance, while $\mathrm{Ni}$ is in $2^{\text {nd }}$ or $3^{\text {rd }}$ place and Mo the $3^{\text {rd }}$ or $4^{\text {th }}$ place (according to the mussel species) in the shell sequence, they appear in $9^{\text {th }}$ and $12^{\text {th }}$ place respectively in the sediment sequence. The differences between the sequences of the tissues and that of the sediments were less striking.

A certain similarity was observed between the element sequences in the macrophytes and in the soft tissues of the mussels, particularly for the more abundant metals $(\mathrm{Ca}, \mathrm{Mn}, \mathrm{Zn}, \mathrm{Cu}, \mathrm{Pb})$. In contrast, the sequences in the macrophytes differed substantially from those in the mussel shells. For instance, lead and molybdenum in the macrophyte sequences were in 6 th and $12^{\text {th }}$ place respectively, while in the mussel shells molybdenum was in $3^{\text {rd }}-4^{\text {th }}$ place (according to the species), with lead only in $10^{\text {th }}$ or $13^{\text {th }}$ place.

Although the chemical composition of the sediments depends on the elements in the water, the sedimentation or precipitation of the elements from the water to the sediment is strictly controlled by their physico-chemical form (e.g. ionic, complexed, particulated) as well as by water characteristics such as $\mathrm{pH}$, alkalinity, particle concentration, presence of chelators, oxygen concentra- tion. This explains the differences in element concentrations and sequences between water and sediments. For example, Mn concentration in the sediments is far higher than in the water (Tab. 1).

Similarly, neither the different sequence of elements in the mussel shells and soft tissues, nor the wider differences between Dreissena (belonging to the Dreissenidae) and Unionidae than between the two Unionidae species are surprising. Macrophytes tissues are obviously more similar to mussels soft tissues than to their shell, the structure and genesis of which account for its distinctive composition. Indeed, the highest differences were between shells on the one hand and both the physical environment compartments (water and sediment) and plant tissues on the other.

Biomonitoring practices commonly used consist in estimating the pollution level of the environment (water and sediments) by analysing the concentrations of pollutants in the tissues of the accumulator species. The basic concept underpinning this practice is that the chemical composition of the organism reflects that of its environment, a statement which is true only to a certain extent. Indeed, all the species display a more or less marked ability to discriminate between elements in relation to their physiological needs and to their sensitivity to toxic and non-essential elements. Some toxic elements can be accumulated in a non-dangerous form in organisms provided with detoxification mechanisms, such as the production of metal binding thyoneins or calcium phosphate granules. Moreover, the extent of accumulation and the physiological half-life of the elements vary widely in relation to the characteristics of both the element and the organism. All these factors combine to 1) determine the differences in the chemical composition of the various species inhabiting the same environment and 2) attenuate or even abolish any relationship between the pollutant concentration in the accumulator organisms and in the water and/or sediment.

Since the results of our study failed to reveal any clear similarity between element sequences in lake water and those in the tissues of organisms (macrophytes and mussels), it was impossible to establish any relationship between trace element concentrations in the bioindicators and the present level of water contamination. Conversely, there was a weak similarity between element sequences in the organisms (macrophytes and mussel soft tissues) and in the sediments. However, this evidence of a possible, even though weak, relationship between bioaccumulators and sediments does not prove that the chemical composition of the organisms is more strongly influenced by sediments than by water chemistry. Indeed, the macrophytes used in this study, despite having roots, take up the metals mainly from the water, and mussels, despite living in contact with sediments, receive their main element supply from the water and suspended particles used as food. 
The process leading to element accumulation in sediments and organisms, such as mussels and macrophytes, takes a relatively long time. Therefore the element concentration in the bioaccumulators cannot reflect the water level of contamination at the time of sampling, while a certain similarity between sediments and organisms, as observed in this study, can be easily explained.

The element content in species with a long life-span is more likely to represent an integrated value of the level of contamination experienced by the organisms over time. This is particularly evident for the mussel shells, which have a very slow turn-over time if compared to the soft tissues. This is an advantageous characteristic which can provide quite accurate information on the variations over time of the environmental level of pollution if the pollutant concentrations in the shell layers can be measured and the layers dated (e.g. Nelson 1964; Westermark et al. 1966; Nyström \& Dunca 1966; Nyström et al. 1966). However, the advantage turns into a disadvantage if the aim is to obtain information on the present situation from analysis of the shell "in toto", since the past accumulation of metals masks the value of the present uptake.

The conclusions of this study are in agreement with Metcalfe-Smith (1994) who stated that since the concentration of metals in the organisms rarely correlates with that in sediments, accumulation monitoring should be greatly improved. Indeed, the results of this research (which mimics the commonly used monitoring practice) prove that bioaccumulators cannot be used to evaluate the pollutant levels of the environment at the time of collection, since no relationship between metal concentrations in the tested and species and those in water was found, and the relationship with sediments was very weak. The most important causes of this are: 1) the accumulation of metals in the organisms is integrated over time; 2) macrophytes and mussels, like any other organisms, can discriminate between elements and regulate their uptake to a certain degree and 3) the bioavailable metal fraction represents a variable percentage of the total metal concentration.

It is clear, then, that this kind of biomonitoring method yields reliable results only when substantial differences in metal concentrations over time or between different environments have to be estimated ${ }^{2)}$. As an example, the variations over time of the radioactive level have been recorded by measuring some fall-out radioisotopes in freshwater and marine molluscs (e.g. Gaglione \& Ravera 1964; Tassi-Pelati 1969).

Bioaccumulators can be regarded as a useful tool in studies of long-term variations of the metal pollution level by following, for instance, the element fluctuations in the same environment. Moreover, the mussel shells

\footnotetext{
${ }^{2)}$ To test this opinion, mussels (Unio pictorum mancus) have been collected from 12 North Italian lakes and analysed for the more abundant trace metals. The data treatment is in progress.
}

can be used: 1) to compare the recent level of pollution with that of past times in the same environment when shell samples of the same species are available (e.g. museum collections); and 2) to follow year to year variations by analysing metal concentrations in the shell layers.

\section{ACKNOWLEDGMENTS}

We are grateful to Dr. Gaetano Galanti (C.N.R.I.S.E., Pallanza, Italy) for his help to classify the aquatic plants and M. Nocolas Diard (Université de Toulon et du Var, France) for his help in chemical analyses.

\section{REFERENCES}

Adams, S.M. \& C.D. Shorey. 1998. Energy dispersive spectroscopy of granular concretions in the mantle of the freshwater mussel Hyridella depressa from Lake Burragorang as a technique to monitor metals in aquatic systems. Aquatic Toxicology, 44: 93-102.

Abo-Rady, M.T.K. 1980. Makrophytische Wasserpflanzen als Bioindikatoren für die Schwermetallbelastung der oberen Laine. Arch. Hydrobiol., 89: 387-404.

Byrne, M. 2000. Calcium concretions in the interstitial tissues of the Australian freshwater mussel Hyridella depressa (Hyriidae). In: E.M. Harper, J.D. Taylor \& J.A. Crame (Eds). The Evolutionary Biology of the Bivalvia. Geological Society, London, Special Publications, 177: 329-337.

Byrne, M. \& P.A. Vesk. 2000. Elemental composition of mantle tissue granules in Hyridella depressa (Unionida) from the Hawkesbury - Nepean River system, Australia: influence from catchment chemistry. Aust. J. Mar. Freshwater Res., 51: 183-192.

Czarnezki, J.M. 1987. Use of the pocketbook mussel, Lampsilis ventricosa for monitoring heavy metal pollution in an Ozark Stream. Bull. Environ. Contam. Toxicol., 38: 641-646.

De Bortoli, M., P. Gaglione, A. Malvicini \& C. Polvani. 1968. Concentration factors for strontium and caesium in fish of the lakes in the region of Varese (Northern Italy). Giorn. Fisica Sanit. Radioprot., 12: 324-331.

Doherty, F.G., D.W. Evans \& E.F. Neuhauser. 1993. An assessment of total and leachable contaminants in zebra mussels (Dreissena polymorpha) from Lake Eire. Ecotoxicol. Environ. Saf., 25: 328-340.

Ferrington, J.W., E.D. Goldberg, R.W. Risebrough, J.H. Martin \& V.T. Bowen. 1983. U.S. Mussel Watch. 1976-1978. An overwiew of the trace-metals, DDT, PCB, hydrocarbon and artificial radionuclide data. Environ. Sci. Technol., 17: 490-496.

Gaglione, P. \& O. Ravera. 1964. Manganese-54 concentration in fall-out, water and Unio mussels of Lake Maggiore 1960. Nature, 204: 1215-1217.

Guilizzoni, P. 1975. Manganese, copper and chromium content in macrophytes of Lake Endine. Mem. Ist. ital. Idrobiol., 32: 313-332.

Jeffree, R.A \& P.L. Brown. 1992. A mechanistic and predictive model of metal accumulation by the tissue of the Australian freshwater mussel Velesunio angasi. Sci. Total Environ., 125: 85-95.

Jeffree, R.A., S.J. Markich \& P.L. Brown. 1993. Comparative accumulation of alkaline-earth metals by two freshwater mussel species from the Nepean River, Australia: consistencies and a resolved paradox. Aust. J. Mar. Freshwater Res., 44: 609-634.

Korringa, P. 1960. Problems arising from disposal of low activity radioactive wastes in the coastal waters of the Netherlands. In: Disposal of radioactive Wastes. IAEA, Wien, 2: $51-56$. 
Lobel, P.B., S.P. Belkhode, S.E. Jackson \& H.P. Longerich. 1990. Recent taxonomic discoveries concerning the mussel Mytilus: Implications for biomonitoring. Arch. Environ. Contam. Toxicol., 19: 508-512.

Markich, S.J. \& R.A. Jeffree. 1994. Absorption of divalent trace metals as analogues of calcium by Australian freshwater bivalves - an explanation of how water hardness reduces metal toxicity (review). Aquat. Toxicol., 29: 257-290.

Mason, A.Z. \& K.D. Jenkins. 1995. Metal detoxification in aquatic Aganisms. In: A. Tessier \& D.R. Turner (Eds). Metal speciation and bioavailability in aquatic systems. John Wiley and Sons, New York: 479-589.

Metcalfe-Smith, J.L. 1994. Influence of species and sex on metal residues in freshwater mussels (family Unionidae) from the St. Lawrence River, with implications for biomonitoring programs. Environ. Toxicol. and Chem., 13: 1433-1443.

Metcalfe-Smith, J.L., J.C. Merriman \& S.P. Batchelor. 1992. Relationships between concentrations of metals in sediment and two species of freshwater mussels in the Ottawa River. Water Poll. Res. J. Canada, 27: 845-869.

Metcalfe-Smith, J.L., R.H. Green \& L.C. Grapentine. 1996. Influence of biological factors on concentrations of metals in the tissues of freshwater mussels (Elliptio complanata and Lampsilis radiata radiata) from the St. Lawrence River. Can. J. Fish. Aquat. Sci., 53: 205-219.

Millington, P.J. \& K.F. Walker. 1983. Australian freshwater mussel Valesunio ambiguus (Philippi) as a biological monitor for zinc, iron and manganese. Aust. J. Mar. Freshwater Res., 34: 873-892.

Nelson, D.J. 1964. Deposition of strontium in relation to morphology of clam (Unionidae) shells. Verh. int. Ver. Limnol., 15: 893-902.

Nagel, K.O. \& G. Badino. 2001. Population genetis and systematics of European Unionidea. In: G. Bauer \& K. Wächtler (Eds). Ecology and evolution of the Freshwater Mussels Unionida. Ecological Studies, Springer, Berlin, 145.

Nyström, J. \& E. Dunca. 1996. Nuclear microscopy of freshwater bivalves. Bull. Inst. Oceanog. Monaco Spéc., 14: 121-125.

Nyström, J., E. Dunca, H. Mutvei \& V. Lindh. 1966. Environmental history as reflected by freshwater pearl mussels in the River Vramsån, southern Sweden. Ambio, 15: 350-355.

Oertel, N. 1998. Molluscs as biomonitors of heavy metals in a side-arm system of the River Danube disturbed by engineering activities. Verh. int. Ver. Limnol., 26: 2120-2124.

Pusch, M., J. Siefert \& N. Walz. 2001. Filtration and respiration rates of two Unionid species and their impact on the water quality of a lowland river. In: G. Bauer \& $\mathrm{K}$. Wächtler (Eds). Ecology and evolution of the freshwater
Mussels Unionida. Ecological Studies, Springer, Berlin: 145: 317-326.

Ravera, O. 1964. Distribution of Mn54 from fall-out in population of freshwater lamellibranchs (Unio mancus elongatulus, Pfeiffer). Verh. int. Ver. Limnol., 15: 885-892.

Ravera, O. 1966. L'utilità delle piante acquatiche nello studio delle contaminazioni radioattive dei bacini lacustri. Giorn. Fisica Sanit. Radioprot., 10: 162-165.

Ravera, O. 2001. Monitoring of the aquatic environment by species accumulators of pollutants: a review. In: O. Ravera (Ed.). Scientific and legal aspects of biological monitoring in freshwater. J. Limnol., 60 (Suppl. 1): 63-72.

Ravera, O. \& L. Vido. 1961. Misura del Mn-54 in popolazioni di Unio pictorum, L. (Molluschi Lamellibranchi) del Lago Maggiore. Mem. Ist. ital. Idrobiol., 13: 75-84.

Ravera, O., R. Gommes \& H. Muntau. 1974. Cadmium distribution in aquatic environment and its effects on aquatic organisms. In: European Colloquium "Problems of the contamination of man and his environment by mercury and cadmium". Luzemburg, 3-5 July 1973. C.E.C. EUR5075. 1974: 317-330.

Stanczykowska, A., W. Lawacz, J. Mattice \& K. Lewandowski. 1976. Bivalves as a factor effecting circulation of matter in lake Mikolajskie (Poland). Limnologia, 10: 347-352.

Sures, B., W. Steiner, M. Rydlo \& H. Taraschwski. 1999. Concentrations of 17 elements in the zebra mussel (Dreissena polymorpha) in different tissues of perch (Perca fluviatilis) and in perch intestinal parasites (Acanthocephalus lucii) from the subalpine Lake Mondsee, Austria. Environ. Toxicol. Chem., 48: 2574-2579.

Tassi-Pelati, L. 1969. Importanza dei molluschi nel ciclo biogeochimico dello stronzio: contenuto di Sr-90 (e Ra-226) nel guscio di Tellina pusilla. Ist. Lombardo (Rend. Sc.) B, 103: 84-92.

Ünlü, M.Y. \& S.W. Fowler. 1979. Factors affecting the flux of arsenic through the mussel Mytilus galloprovincialis. Marine Biology, 51: 209-219.

Vesk, P.A. \& M. Byrne. 1999. Metal levels in tissue granules of the freshwater bivalve Hyridella depressa (Unionida) for biomonitoring: the importance of cryopreservation. The Scence of the Total Environment, 225: 219-229.

Walker, K.F., M. Byrne, C.W. Hickey \& D.S. Roper. 2001. Freshwater mussels (Hyriidae) of Australasia. In: G. Bauer \& W. Wächtler (Eds). Ecology and evolution of the freshwater mussels Unionida. Ecological Studies, Springer, Berlin, 145: 5-31.

Westermark, T., B. Carell, S. Forberg, H. Mutvei \& E. Kulakowski. 1966. Freshwater unionid (Mollusca: Bivalvia) shells as environmental archives: methodology and observations. Bull. Inst. Oceanog. Monaco Spéc., 14: 73-81. 